University of Rhode Island

DigitalCommons@URI

Open Access Master's Theses

1982

\title{
The Role of the Boston Redevelopment Authority in the Planning and Implementation of Copley Place, Boston, Massachusetts
}

Margaret M. Horak

University of Rhode Island

Follow this and additional works at: https://digitalcommons.uri.edu/theses

\section{Recommended Citation}

Horak, Margaret M., "The Role of the Boston Redevelopment Authority in the Planning and Implementation of Copley Place, Boston, Massachusetts" (1982). Open Access Master's Theses. Paper 644. https://digitalcommons.uri.edu/theses/644

This Thesis is brought to you for free and open access by DigitalCommons@URI. It has been accepted for inclusion in Open Access Master's Theses by an authorized administrator of DigitalCommons@URI. For more information, please contact digitalcommons-group@uri.edu. 
THE ROLE OF THE BOSTON REDEVELOPMENT AUTHORITY

IN THE PLANNING AND IMPLEMENTATION

OF COPLEY PLACE, BOSTON, MASSACHUSETTS

\section{A RESEARCH PROJECT SUBMITTED IN \\ PARTIAL FULFILLMENT OF THE REQUIREMENTS \\ FOR THE DEGREE OF MASTER OF \\ COMMUNITY PLANNING}

UNIVERSITY OF RHODE ISLAND

1982 
MASTER OF COMMUNITY PLANNING

RESEARCH PROJECT

OF

MARGARET M. HORAK

Approved:

Major Professor

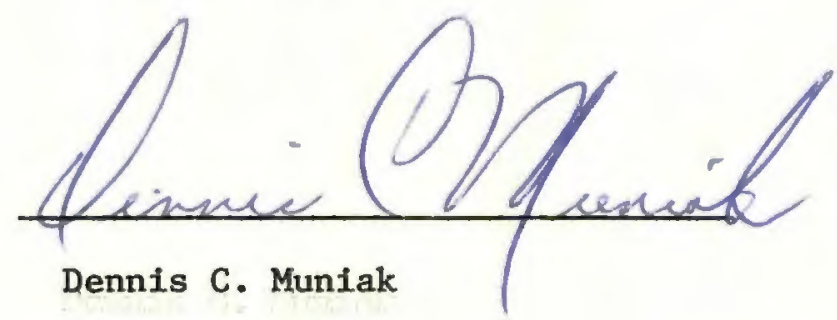

Director

Thomas D. Galloway 


\section{Table of Contents}

I. Introdiction

II. The Development Framework

III. History of the Site

IV. The Planning Process

V. Analysis and Conclusion

\section{Appendices:}

A. Memorandum of Understanding, between State and UIDC

B. Citizen Review Comittee: List of Meetings

C. BRA Response to Administrative Complaint, Brecutive Sumary

D. Copley Place: Fact Sheet, UIDC

F. Copley Place: Press Release, UIDC

Maps and Designs:

Copley Place: Site Location

Copley Place: Site Constraints

Copley Place: Ground Level Bullding Plans

Copley Place: Site Location, Model, Program Components

Bibl lography 


\section{Introduction}

Coplew Place, a $\$ 350$ million mixed use development in downtown Boston, is unique in its size and diversity. The development entalls two major hotels, a convention facility, an up-scale department store, 260,000 square feet retail space, cinemes, 800,000 square feet office space, and 100 units of mixed-income housing. The history of the development - the transition from concept to reality - is quite complex.

The developer, the Urban Investment Development Company (UIDC), first expressed interest in the site in early 1977. The groundbreaking ceremony took plece in November, 1980. The three-and a half yeara in between were filled with negotiation, trade-offs, and co-optation. The early part of the process comprised leasing agreements from the State of Massachusetts for the site, a 9.5 acre land-air parcel above the Mass Turnpike in Back Bay. A Citizen Review Committee participated from the beginning. The latter part of the process involved the city of Boston in the application for a federal Urban Development Action Grent (JDAG).

The development process of Copley Place signals a unique siplementation of public and private interests. The circumstances leading up to the groundbreaking and beyond ereate an intrlguing account of bargeining and special interest pressures. The magnitude of the project will result in, and has already witnessed, strong implications for the adjacent neighborhoods and the City of Boston. 


\section{The Development Framework}

Local goremment is playing an increasingly important role in urban investment. Having recognized that the economic growth rate lies In the birthrate of new business (Cornia, 1978 p.--), public officials have begun to cievise ways of attracting investment and shaping it to maximum public benefit.

Public officials have demonstrated an ability to exert themselves successfully to affect their fiscal well-being. With the goal of bringing positive impacts on employmenth local tax base and business activity, the public sector is using both philosophical and active tools to work with potential developers. Philosophically, the importance of offering a receptive political climate cannot be understated. As a developer weighs the investment optjons, a public official can offer a hospitable and attractive community environment that may help to persuade the decision (Comla, 1978, p.--). The developer must work with the public officials - an amicable relationship from the beginning can help to foster a working alliance advantageous to both sides.

The public sector may also employ active intervention techniques in the development process. The city has the traditional tools of zoning and service delivery at their disposal, as well as more innovative development controls (HUD, 1980, p.16). The use of density bonuses can work to concentrate development in designated areas; the offering of air rights and site parceling can bring development, as with Copley Place. But the Key to the success of these tools is that they mesh with market 
trends. Substantial development interest, regardless of public intervention, is Jased upon profit motivation.

Because the public and private sectors are so different in their orientation, it is cruclal that they understand one another. The public sector must strive to determine market forces, to identify the community's assets in terms of development criteria, and to leam effective packaging echniques. With a thorough understanding of what the private investor is looking for, the publio official can package an Idea for development consideration.

In addition to a warket understanding, the public sector must have a financial understanding of the development process. An official at the Boston Redevelopment Authority has stated that the financial requirements of a developer are legitimate (Hollister, 1980, p.28). A lengthy planning process and uncoordinated public sector intervention cost a developer a large sum of money, enough in fact, to reault in the inability to actually construct a project. If a developer strings out his assets during the planning stage, then he can risk the construction capital needed to begin. The oity can help immeasurably by being prepared for potential development projects. The economic growth or revitalization of a community is promoted by cutting down on bureaucratic red tape which slows the process (Cornia, 1978, p.--). The city can strive for interasency coordination to alleviate misunderstanding and inefficiency. Also, commity involvement is crucial during the planning process to avoid problems during an impact assessment which costs a deveioper. Economic development requires a partnership which is the critical ingredient in areas of financial feasibility, timing and location (HUE, 1980, p.21). The joint venture between the pollic and private sector 
ectors is often the answer to insuring smooth development projects. The partnership, from the beginning, helps to ensure a development that occurs more expeditiously, with success for both parties. The cooperative public/private investment trend is a relatively new phenomenon. The gradual realization that businesses were choosing to locate in suburban and exurban areas resulted in an attempt for a more active local participation in development decisions. The public sector, in agsuming the role of partner, is bringing a new level of expertise into the more traditional "reactive" position played by a local official in the past. The evidence of involvement is found in the formalization of public/private development ventures and the skill and sophistication of public personnel in the planning and implementation of projects in their community (INCUED, 1978, p.1).

The role of the local official and the developer varies according to a number of factors (U.S. Conf, of Mayors, N.D. p.1). The economic situation may call for a financial partnership in which the public sector leverages private investment with public dollars, as with the Jrban Development Action Grant (UDAG) program. Initiated in 1977 under the Dept. of Elousing and Urban Development (HUD), the program requires a leveraging ratio of at least three to one private/public dollars. The offer of public money is used to persuade investment in declining urban areas to promote jobs and revitalization.

Another factor which shapes the role played by each partner is the political setting (US Conf. of Mayors, N.D. p.1). The public sector should assure a favorable governmental and community attitude. From 
the developer's perspective, there is a great need for consistency of treatment by govemment along with a flexibility of public assistance. (Borut, 1979, p.4). In cages where political in-fighting overcome consistency and reception, a developer may assume a more offensive role, thereby destroying a worising partnership.

Motivation and capacity also help to set the role of the partners (US Conf. of Mayrors, N.D. P.1). Obviously, the extent to which each partner is committed to the project determines the degree of voluntary participation. Cooperative efforts are most successful with an underlying concensus between the public and private sectors that their partnership is a necessary condition for urban reinvestment (US Conf. of Mayors, N.D., p.1).

However, some feeling exists among urban activists that private investment is not always the best answer. According to Frank Smizik of the Mass Law Reform Institute (the organizgtion representing 8 South Fnd, Boston residents who are suing HUD and the City of Boston because of the displacement that will result from Copley Place - HUD has granted an $\$ 18.8$ million UDAG for the project), private investment, leveraged with public money, is considered the solution to blighted areas. He feels thet too often, these projects go ahead without the consideration of all of the impacts. He has "no quarrel with private investment, but there must be a plan to handle its impacts on minorities - particularly In a ofty like Boston where they have no place to go if they're displeced." Therefore, local officials involved in economic development planning must balance the desires of profit-motivated developers againgt 
the public interest goals of the community (MUD, 1980, p. 10). The immediate outputs of a development project - expanded tax base and job creation - must be weighed in terms of the real outcomes-displacement. The concept of leveraging orfvate invegtment and providing supportive market conditions is at the heart of urben economic developnent planning (NCOET), 1978, p.1). To maintain a viable economy, the public sector must join hands with potential developers and take a stand in what happens to a community. The basic components in support of development are a favorable attitude, flexible tools and knowledgeable personnel (Boru.t, 1979, p.4). When utilized properly and to the best advantage, the public sector can effectively guide private investrent by employing the available tools of land use and zoning, infrastructure and property tax abatement. Preparedness works to avold the destructive polarization between pablic and private actors (Hollister, 1980, p.22). 
The Copley Place Site had been a vacant parcel for over 20 years. In the late $1950^{\prime}$ 's, the area was cleared for the Mass. Turnpike Extension into Boston. Before that time, the South End was joinad physically and architecturally with Back Bay. Huntington Ave. had been lined with fine, old buildings that integrated with the historically significant structures nearby - the Boston Public Iibrary, the Copley Plaza Hotel, and Prinity Church. Nearby, the Prudential Center was built on a site of old railroad yards, further 'cleaning up' the area. Since the building of the turnpike, the City has attempted to identify an appropriate development for the site.

In the 1965 Boston General Plan the city planners called for a large-scale developmert on the site to work in conjunction with a new Back Bay Transportation Center. However, nelther plan was implemented. The priorities for development were placed elsewhere in Back Bay with the Prudential Center expansion in the 1960's and the John Hancock Tower in the 1970's. Even though several architectural firms attempted to devise a development scheme that would overcome the severe physical constraints of the site, none could achieve an economically viable solution.

The structural difficulties of the site are due to its location both next to and over the Massachusetts Turnpike. A develoment would have to be built on air rights. The site's physical constraints involve access problems with the Turnpike exit ramps, and the Amtrak rail tracks and platform. 
Until recently, the City was unable to attract serious development proposals. The City's Comprehensive Economic Development Strategy prepered with U.S. EDA funding, called for a targeted development in the area that would overcome these constraints - one that would stimulate investment and the creation of jobs. The Strategy is part of a program instituted to counteract the effects of job losses and the shift to greater specialization in services, which result in high unemployment among minoritiea and low-income persons.

Several factors contributed to the recognition of the Copley site's potential for a large-scale profect. The tremendous demand for available office space in Boston encouraged an attempt to devise a feasible plan. Boston's rental office market is one of the strongest in the cantry with an occupancy rate hovering near $99 \%$. The rent-up of the Hancock Tourer put an end to the availability of office space in the Copley Square area. With the Boylston Street retall area facelift, referred to by some as the "uptown Faneuil Hall," a strong demand for additional retail space arose.

Physical improvements to the surrounding have made the site more attractive. The renovation of the Copley Plaza Hotel and the completion of the Boston Public Ilbrary addition provided significant contributions to Back Bey appearance. Also, the Sheraton Hotel expanded successfully and the Saks Fifth Avenue store was added to the Prudential Center. Finally, firm plans for the reconsturction of the Back Bay Amtrak Railraod Station were made. These plans include realignment of the 
Southwest Corridor* and the addition of a new rapid trunsit route (the Massachusetts Bay Transit Authority (MBTA) orange line) with a mejor stop at the Back Bay station. As an indicator of commitment, in March 1982, the MBTA announced the trasferral of $\$ 2.5$ million from the rider shelter program to the funding for the reconstruction of the Station.

The combination, therefore, of both physical improvements to the area, and strong State and City commitment to a Copley Place proposal, prompted renewed developer interest in the site. The development now undes: construction was proposed by the Urban Investment Development Company (UIDC), a division of Aetna Iife Insurance Corp, in early 1977. The development opportunity followed years of political negotiation with the Park Piaza project**, another development scheme for downtown Boston, City officials were sensitive to repeating a similar hassle. With the Park Plaza incident, the Boston Redevelopment Authority (BRA) published development guidelines and solicited bids in a competition. A developer for Park Plaza was designated and his detalled plans were then subjected to a 1971 state Environmental Impact Review (EIR). The plan drew public uriticism and delayed approval of the project for three years. By this time, a supplemental EIR was required to update the assessment. The original developer withdrew because of the lengthy planning process, and ten years were lost. When approached with the

*The Southwest Corridor was a highway planned to link downtown Boston with the suburbs to the southwest. Under the highway moratorium imposed by Gcv. Francis Sargent, the land was turned over to the MBTA for use es a rapid transit southwest line.

**Park Plaza, located about mile from the copley Site, had been a development scheme proposing a hotel, retail, and office space. 
Copley proposal, the City and State were determined not "s commit the seme error.

\section{The Planning Process}

The developer, JIDC, was required to engage in a two phase negotiation process: first, with the State, and second, with the City. The site was owned by the Massachusetts Turnpike Authority, so UIDC needed first to negotiate for use of the property. Then, the city became involved as the central public participant in the process with permit approvals and the Urban Development Action Grant application.

The selection of UIDC as the developer for the Copley site marks a unique process of a front-end approach to impact assessment (Hollister, 1980, p.22). JIDC demonstrated interest in developing the Copley Place site in early 1977, and the state decided to grant an option on the property for a 6-month period wile proceeding with the citizen review and Impact assessment. State Planning Director Frank Keefe advocated the early desienation of a developer to speed the planning process. UIDC was seen as a strong developer with a good track record. UIDC is a whollyowned subsidiary of Aetna Iffe and Casualty, "the netion's largest diversified financial organization," according to a company brochure. The most recent development completed by UIDC was Chicago's Water Tower Place, a 3.1 million square ft., 74-story mixed-use complex (UIDC, 1982). The Governor Michael Dukakis agreed to Keefe's plan, and on April 18, 1977, the Massachusetts Turnpike Authority (MTA) sigmed a Menorandum 
of Understauding with UIDC "during which UIDC will engage in engineering and market analyses and the Turnpike Authority will refuse to negotiate or lease its Copley Square land and air rights to any other party ... at the end of six months, everyone will have a full understanding of the constraints and opportunities at Copley Square, and a decision can be made by both the developer and the state and the city public sector agencles as to whether it makes sense to proceed into an option" (Keefe, 9/22/77).

UIDC approached the state with the support of the Western International Hotels who were committed to bullding an 800-room luxury hotel as part of the Copley Place program. Western had approached the state earlier, alone, with a plan to build a hotel on the land section of the parcel, but could not convinoe the MTA to agree (Hollister, 1980, p.30). The inclugion of a hotel. met with favor from the public officials. A BRA study, completed in 1976, concluded that, "In order to optimize its competitive position, Boston needs convention-oriendted hottl rooms providing 1600-1800 rooms and located in proximity to its convention facilities" (BRA, 1976, p.4): namely, the John B. Hynes Auditorium, located 3 blocks form Copley Place. The demand for hotel space was keen, and a developer with a major hotel chain in hand was welcome., With the Memorendum of UnderstandinB, UIDC began planning the development. At that time, basic issues of site usage, massing, and the interrelationships of the program elements were considered. The initial intention was to design the tall bulldings away from copley square to reduce the perceived scale (JIDC, 1980, p.5). As the schematic plans progressed, UIDC attempted to lacate tile tall buildings away from 
the Tumpike ramps to avold construction of major structures over the greatest site obstructions.

The state brought in the city as a participant in the oversight of the plaining, the Boston Redevelopment Authority (BRA) acting as the City's representative. The Office of State Planning organized the Citizen Review Conmitte (CRC) under the direction of Ir. Tunney Lee of MIT. In May 1977, the CRC group members were selected and assembled. The CRC was made up of neighborhood organizations from the South End, Back Bay, and the Fenway sections of Boston. The organizations riere representative of virtually all the impacted persons, both middle-class professionals and low-income minorities. The Back Bay tederation represented area businessee and institations. In all, the $\mathrm{C} P \mathrm{C}$ membership and its variety bighlight the complex issues involved with Copley Place (Hollister, 1980, p. 34).

Participation by the public in. reviewing a project the size of Copley Place is unprecedented in Boston. According to Teri Weidner, Director of Communications at UIDC, the CRC process was more extensive than any other with which UIDC had been involved. M.s. Weidner states that the entire citizen participation process amounted to an expense of $\$ 6$ million to the developer (feidner interview). In the beginning, UIDC was not certain as to how extensive the CP.C involvement would be, but it soon became clear that the State and City were, at this point, behind the process and would back the citizens (Hollister, 1980, p.38).

The CRC process began in earnest. The deadline for their firal recommendations for the project was september, 1977, which allowed only 
3-4 months review. A total of 19 meetings were held throughout that first period. The sessions were devoted to issues of community economic development, neighborhood stability, impact on business, physical design, and traffic impact - addressed by individual task forces within the CRC (UIDC, 1980, p.5).

Lee directed the early meetings to provide a basic level of understanding. These early workshops offered information regarding the physical and social environment, legal requirements, and the developer's perspective (Hollister, 1980, p.35). Various technical experts were on hand to answer questions, such as the state's Central Transportation Plenning Staff. Lee himself dealt with questions concerning physical planning. A UIDC official, Dan Gifford, lectured on real estate developnent, anci a state planning representative handled regulatory control ouestions (Gollister, 1980, p.35). (note: There was very little newspaper corerage of copley at this point. The BRA file begins with their involvement in the process).

Throughout the summer the CRC met, and at the end of June, an Interim report specified certain issues of concern. These issues included physical design, land use, jobs, pedestrian access, traffic, housing, wind and shadows, and economic impact (UIDC, 1980, p.5). Further development in workshops resulted in CRC Final Pecomendations, delivered September 22, 1977. The recomendations took form as goal statements followed by general guidelines for action and specific steps to take to achleve the desired end. The goals were as follows: (1) Communty Economic Development; (2) Setail Impact; (3) South End Stabilization; (4) Staging; (5) Vassing; (6) Land Use; (7) Pedestrians; (8) Traffic; and, (9) Gnvir- 
onmental Impact (CRC, 1977). The 1ssues brought up at this early point in the planning process remained in the negotfations until the end. Meanwhile, as the Memorandum of Understanding had called for, UIDC undertock its own feasibility studies (UIDC, 1980, p.5). The UIDC planners were conceptualizing the size and scale of the various project components, the hotel, retall, and office spaces. It became clear that the bridging of the Turnpike, ramps, and rail tracks would be enormously expensive. According to UIDC, it was at this early point in the planning that some sort of public subsidy was seen to be necessary, as well as an expanded plan to help absorb these costs.

UIDC considered over a half-dozen design concepts during 1977 (UIDC, 1980, p.16-34). Each was modified to include the imformation from the consulting studies. Finally, 3 alternatives were presented to the pubI1c which provided a "workable concept plan" (UIDC, 1980, p.6). A scale model was developed to illustrate the conclusions of the analysis. The CRC recommendations were incorporated into the 3.alternatives. The recomendations called for 3 major modifications: (1) Housing - UIDC agreed to the inclusion of 100 units of mired-income housing after the State and City offlcials insisted upon following the CRC 1dea; (2) Parcel "C" - UIDC agreed to develop th1s paroel (it is the designated area for the Neiman-Marcus degartment atore in the profect) on Dartmouth Street, which they had proposed to leave vacant; (3) Access - UIDC agreed to provide better vehicular and pedestrian access into and around the project (UIDC, 1980, p.7).

The design modification process continued, and in June, 1978, UIDC 
presented a revised yreliminary design which they felt was both financlally feastble and in conformance with CRC guidelines. The June 1978 desion consisted of 1 hotel, 2 department stores, a shopping mall, an office bullding, a parking garage, and the housing. At this point, the design process was frozen so that the approprlate drawing could be articulated. This desion also became the basis for the environmental impact stadies, which were inftlated during the summer of 1978 (UIDC, 1980, p.8). At this time, Keefe announced that the site and air rights would not be sold to the developer, fee simple, but rather the MTA would lease the property to UIDC. The negotiations for a lease rent schedule began since the basic 1saues of construction were resolved. (Hollistex, 1980, p.40).

The CRC, which had been dormant since the september, 1977 Final Recommendations, was reactivated to review the latest design proposal. Throughout the summer, the CRC met at 7 workshops to discuss impacts that were not addressed in detall during the previous sumer. This second phass of the CRC was organized by Prof. Lee. In Lee's worda, this phase of the CRC process was, "to keep the scheme within acceptable limits. The analysis of impacts that occurred during the second half of 1978 did not directly change the development scheme, but it made the lease agreement possible and acceptable" (Holl1ster, 1980, p.41). The impect 1msues dfecussed were effects on Back Bay businesses, population composition of surrounding neighborhoods, alr quality, and other environmental impacts (UIDC, 1980, p.195).

In Ootober, 1978, the Draft Environmental Impact Review (EIR) was 
released by the conoulting firm hired by DIDC, Environmental Research and Technology, Inc. However, earlier that Fall, UIDC announced a desiEn change that included at third department store. The consultants did not have sufficlent time to fully assess the impact of the preferred design, so they extrapolated the original design impacts to expand the analysis. The CRC and the public officials accepted the EIR, but insigted upon a more complete analysis at a later date. However, before the end of the year, UIDC again revised the design, to reduce the retall and increase the hotel and office components (UIDC, 1980, p.8). It was felt that the Boston market could not sustain 3 department stores (earlier interest expressed by potential department store tenants had softened), wh1le demand mushroomed for the other types of deveopment. During the spring of 1979, the design work concentrated on a two-hotel, 1-department atare procram.

Meanwhile, political events at the state level temporarily confused the negotiations. Governor Dukakis and his advisors hed been working both with the developer and the City since the inception of the project. Keefe, the director of State Planning and Fred Salvucci, Transportation Secretary, had been instrumental in representing the state's interests. Interestingly, Salvaccl bid formerly been an afde to Mayor Kevin White, and worked as a key liason with City Hall (Holl1ster, 1980, p.54). However, Dukakis was upset by Edward King in the Democratic Gubernatorial Primary In september, and King went on to win the election. The lease signing date had been targeted for December 15, but the prospect of a new administration was potentially unsettling. 
UIDC chose to continue working with the Dukakis administration, and marathon negotiation sessions were held in December. UIDC felt that working with a new set of state officials would delay the project at least one construction season (Lee, p.43).

The points that held up the lease signing were affirmative action and the rent schedule. The State, as would the $\mathrm{Clty}$, wanted assurances that at least $25 \%$ of the construction jobs would go to minority residents. The rent schedule wos complicated, and there wene misunderstandings between the State and OIDC. The State comprimised with the affirmative action portion of the lease, decreasing from a required $25 \%$ to $20 \%$ of the fobs to be minority. However, the state refused to negotiate the rent subordination schedule (Hollister, 1980, p.43). The State, In fact, threatened to decline a lease agreement with UIDC, and advertise for a new developer. Given the impending termination of the Tukakis administration, the threat implied an ultimatum of "deal with us, and know what you heve; or wait for the new adninistration, and see what you might get." (note: The only state actor who would continue into the King administration, John Driscoll, Chairman of the Massachusetts Turnpike Authority, did not play a major leadership role in any negotiations, according to Frank Keefe).

In the end, the bargaining sessions were successful. The State and UIDC officlally solidifled their relationship at a lease signing ceremony on December 22, 1978. The media proclaimed the event as the fitting last chapter in the Dukakis administration -- one that had such a strong polfcy for urban developement. Yet, "the largest comercial development 
in stete history" (Globe, $12 / 23 / 78$ ), was not completed. In reality, it var just beginning. The state actors were finished with their major involvement, and the City stood ready to continue the negotiation process and to issue the necessary permits.

Returning to the design process, the developer had revised the ortsinal 2-store/a-hotel scheme to a 3-store/1-hotel soheme, and finally, to a 1-store/2-hotel scheme. As these details were worked out by the architect, the CRC reconvened and began assessing the impacts in light of these changes (IIDC, 1980, p.9). Between February and Norember, 1979, CRC held 14 meetings to assess the impacts and re-examine the issues not adequately addressed in the 1978 sessions.

As a result of the CRC sessions, 2 new studies were comissioned by the BRA. The CRC determined that the housing and retail impacts needed to be studies further. A local consultant, Mark Waltch, was hired to advise the CRC on the analysis of the impacts (Hollister, 1980,p.41). Waltch helped the CRC to understand and critically review the analyses resulting from the BRA commissions(DIDC, 1980, p.9).

The newly completed studies were released at the end of 1979. The CRC taskforces on the housing and retail issues also released their own Summary Analyses. The CRC conclusions that were drawn resembled those of the BRA-commissioned studies: the retall impact would be beneficial to extstine area businesses by drawing larger numbers of shoppers into the ricinity (CRC, 1979); the housing impact would result in some displacement (recognized as an ongoing national trend, however), but the addition of 100 units within Copley Place and the further impetus to develop the 
Tent City site, would work to counteract gentrification (CRC, 1979). (uote: Tent City is a 3.3 acre site adjacent to the Copley Place project which has been residentially vacant for over 15 years. The site earned Its name in 1968 from squatters who lived thore, in tents, to protest the City's lack of commitment to rebuilding low-income housing. The City argues that the site is non-assemblable. Two-thirds of the pleoe is owned privately, and is unarailable)

In addition to reviewing the updated retall and housing impact studies, the last CRC meetings held in 1979 included discussions about the city application for an Urban Development Action Grant (UDAG). The ODAG was required since the State did not agree to "subsidize" Copley Place with either a $121 \mathrm{~A}$ tax abatement (a state approved property tax abatement in lias of a set yearly foe, a concept designed originally for the Prudential Center), or a land cost relief. The developer had firat expressed the need for some form of public funding in the summer of 1978. The necessity of applying public funds to cover the exorbitant site preperation costs had been acknowledged from the initial negotiations with the the state (UIDC, 1980, p.8).

The BRA agreed to apply for a UDAG and began the information preparation process. Public input was sought by the city with regard to not only the UDAG application, but also the other publio approvals in the process. The BRA worked with the CRC to outline a meeting format for the first public UDAG hearing to be held on November 19, 1979. (Two publ10 hearinge are required in the DDAG application process, one for preapplication input and the second for final application approval). 
Before the meetings, background information wan mailed to all CRC members and other interested organizations. At this point, it was hoped by CRC that the Tent City funding request of $\$ 5$ million could be tied into the Copley Place UDAG application. State Representative Mel King, from the South Find, waw the Copley PIace UDAG as a chance to leverage subsidized housing on the Tent City site (Boston Ledger, 4/18/80). As a type of trade-off, the accelerated population change that would regult from Copley Place would be negated by glving the low-income persons a secure fature in the area.

The meeting was held at 7:00 P.M. at the Boston Public Library. The meeting was chalred by William Holland, Director of the Magor's Office of Pablic Service, and seated on the panel were Kenneth Himel, VicePresident of UIDC; Steven Eiser, Project Manager of Copley Place at DIDC; Richarl Garver, Deputy Director of the BRA; Jeffrey Chmura, Project Coordinator of Copley Place at BRA; and George Bennett, Director of the Employment and Economic Policy Administration. The format of the meeting was set and formalized in an opening statement by Holland, which was followed by introductory remarks given by Eimer, Garver, and Bennett. Tostimony from the public was then requested. Thirty two persons spoke. The mejority of the testimony was addressed to a linkage with Tent City. The feeling among many of the speakers was if there would be cne UDAG, there should be two. It was seen as a way to combine city and federal goals of leveraging private investment with the community goals of low-income housing. (note: A UDAG may be used for low-income housing) 
Those who spoke against Tent City argued that it might serve to jeopardize the success of Copley Place. Although Tent City was not directly the subject of the hearing, the mood of the meeting was set by the emotional issue (UDAG Testimony, 1979).

Others who testified spoke to the question of the extent of social impacts of Copley Place. The residents of the South End, testifying on behalf of their neighborhood,exhorted the city to consider and mitigate the harmful effects of Copley Place. Ralph Jordan, a resident and former Chairperson of the CRC Task Force on Community Econonic Development, noted that, "when public funds are used on a large scale to assist a private developer, those funds must be used to the greatest extent possible to provide jobs and other economic opportunities to economically disadvantaged citizens, particularly those whose own lives and lives of family and friends are so greatly affected by this development. The City must provide leadership to prove to all those living in the City that it cares, and that the Mayor will make sure the people of Boston get their fair share" (UDAG Testimuny, 11/19/79, p.72).

The City had made it clear earlier that the UDAG would not be $100 \%$ Erant money. The developer initially asked for an outright grant, but the City took the position of requiring a return of a portion of the money, according to a BRA spokesperson (Dick Garver, 11/19/79). The developer needed the entire sum immediately, but later, after the construction would be completed and profits from the operation would begin, the developer could afford to repay the loan with interest. The terms of the repayment amount and schedule were not known at the time of the 
November meeting, but were in the process of negotiation. It had been anticipated that the terms sould be worked out and a UDAG written by the January 31, 1980 deadline for applications. However, the repayment schedule and the jobs issue became the focal points for BRA - OIDC negotlations during the ensuing months.

While the UDAG negotiations and desion development continued, the State amended 1 ts lease agreement with the developer. Since the Copley Place program had changed in composition during the summer of 1979 (the reduction of reteil and department store space and the increase of hotel and office space), the MTA revised its rent payment schedule. The Air Rights Lease of Deceuber, 1978 was amended with the new financial terms on January 31, 1979 (JIDC, 1980, p.10). The new lease was signed by UIDC Chairman Thomas Klutznick, the new Governor, Edward KIng, and MTA Chairman John Driscoll. The affirmative action requirements were unchanged, and the CRC process was extended to the end of May, 1980 (UTDC, 1980, p.11).

The focus of the winter of 1979 and the early spring of 1980 was the ODAG epplication. The BPA and the developer put concerted effort into working out the detalls. Described es an"iterative process" by Lucas DiLeo, Project Coordinator of Copley Flace for the BRA, the negotiations were a continual interaction between the BRA and OIDC. The legal, financial, design, neighborhood impact, employment, and environmental issues were all intertwined in the UDAG discussion. By April, the negotiation centered around two major areas of the application: (1) the financial terms of the DDAG - the total amount, the ratio of loan to grant, 
the method of repayment of the loan portion, and the basic terms of the business agreement; and, (2) the affirmative a-tion gufdelines to be followed both for jobs and minority contracts during construction and for the permanent employment opportunities (UIDC, 1980, p.11).

The financial terms were worked out early in the month (Globe, $4 / 10 / 80)$. The amount of the UDAG was set at $\$ 18.8$ million, $\$ 3.8$ million of which would be a grant to the project, and $\$ 15$ million of which would constitute the loan. The repayment of the loan, which won't begin until 1984 or 85 , will amount to $\$ 42$ million over the 27 -year life of the loan. The monles collected will be put into a Neighborhood Development Fund to be superised by the city Council. The interest rate for repayment was set at $10 \%$, when the current mortgage rate was $13 \%$ at a commercial bank.

The payback represents an innovative measure in the UDAG for Copley Place. The Mayor had issued an Executive Order in 1979 regarding the creation of a neighborhood developpent fund as a symbol of the city's desire to make sure that the economic benefits resulting from private investment in the City are not allowed to escape from it. The BRA, from the beginning, committed itself to using the recycled federal monies in the impect areas of Copley Place. At a time when the effects of Copley Place would begin to be felt, the money from the payback could be used to help mitigate displacement and assist low-income housing (UDAG Testimony, 11/19/79, p.18). Also, the BRA mentioned use of the payback to help community businesses start up operation in the neighborhood retail section of the Copley Place development. 
The CFC held a meeting on April 14, 1930 to revlew the UDAG application. In preparation for the second of the two required UDAG publ ic hearings, to be held the followlng day, the CRC members considered all the sections of the application except those referring to the jobs agreement, which wes yet unresolved. The April 15 reeting was a City Council Committee hearing. The Council Comittee on Planning and Develophent reviews all draft UDAG applications, taking testimony from the public, the applicant $B R A$, and the developer.

Thirty persons testified at the meeting, including residents of the South Bnd, business leaders, and constmuction workers, who were concerned about the jobs issue. As with the November public hearing, the Tent City issue was raised. However, the meeting's consensus was one of qualified support of the UDAG pending final ratification of the jobs 1ssue (UDAG Testimony, 4/15/80). The construction workers, while pleased with the prospect of employment, feared that the stringent resident requirements would jeopardize jobs for the ailing industry (Globe, 4/16/80). As Teri Weidiner, spokesperson for UIDC, observed, the heavy steelworkers are not from the city of Boston - many are not even residents of the State. Unions will not allow the unqualified to work, so the developer volced concern over strict residency requirements as well at subsequent UDAG hearings on April 28 and 29.

The deadline for applicetion was April 30. The adamant stance taken by the city and pitched by Mayor White was jobs for residents. Affirmetive action guldelines were included in the MTA lease, as mentioned previously, but the city was holding out for residency. White, in a press 
conference, told reporters, "I want this project in Boston. But I also want $50 \%$ of the jobs from the project to go to Bostonians. I feel strongly about this issue, and we are negotiating now. It is an obstacle which could jeopardize the future of the Copley Place projectn (Herald American, $4 / 10 / 80)$

The newspapers followed the progress of the negotiations throughout the last week of April. The consensus seemed to be that everyone wanted the project, but with that important "if." The developer argued that the affirmative action requirements set in the Air Rights Lease were precedent-getting, and strict enough. UIDC could only try to meet percentage goels for permanent jobs, and could not meet those percentages for construction jobs because of a challenge by the construction industry that was then in court (Weidner interview). The construction industry had brought sult against the City in challenge to Mayor White's Executive Order requifing 50\% of construction jobs be given to residents. UIDC did not want to be caught in the middle of the legal battle, and preferred to sidestep the requirements, and specify goals instead. It was that difference between the developer's goals and the city's requirements that was the difference between eiming at a target and hitting it. According to an analysis of the negotiations printed in the Boston Ledger, the jobs egreement hold-up was making everyone unhappy (Ledger, Week of $4 / 18-24 / 80)$. UIDC was unhappy because it wanted to make the April 30 UDAG deadline to avoid another 3-month dealy in the project:s groundbreaking (UDAGs are awarded quarterly). The commot ty was unhappy because they were excluded from the negotiation, and could only testify at infrequent public hearings. The BRA was unhappy because it feared another 
"Zuckerman" (Zuckerman was the developer who walked out of the Park Plaza project about which the City was so sensitive), and because the agency was caught between the developer, the mayor, the legal challenge, and the community residents.

The public hearings held on April 28 and 29, at sessions of the Council Committee on Planning and Development were emotion filled. The 11 th hour negotiations caused some complaint from those who felt that they did not have adequate time to review the IInal UDAG application (Globe, 4/29/80). Councilmen Ray Flynn blemed the lack of time on the BPA, and on the day before the submission deadline, he threatened to vote egainst the application in order to fully review the terms (Globe, 4/29/80). The Compltee reported out the Application on the evening of April 29. The final application had several amendments attached pertaining to the jobs agreement and the financing schedule. The application was eent to the full city council for consideration on the 30th. The jobs agreement, was decided as goals for hiring residents, rather than the requirements. The hiring goals for construction call for $50 \%$ of the jobs for Boston residents, 35\% for minorities, and 10\% for women. The Attainment of the goals would be monitored by a comittee couposed of union and contractor interests. The only requirements were those pertaining to affirmative action, al ready agreed upon in the Air Rights Lease.

The agreement set goals of hiring Boston residents for $50 \%$ of the 6000 permenent jobs resulting from the project. The developer agreed to encourage future tenants to abide by these goals, which include $50 \%$ of 
jobs for women and $30 \%$ for minority. Detaik on enforcing the goals were not arranged at the time of the UDAG application. Instead, it was decided that Mayor White would meet with the major tenants and work out Indfvidual agreements. According to Robert Ryan, Director of the BRA, the jobs agreements "will reach the City's goals" (Globe, 4/29/80).

On April 30, the full Council unanimously approved the UDAG appl1cation on the recomendation of the Committee on Planning and Developeient. Several councilmen, while voting affirmatively for the JDAG, voiced reservations concerning the project. Councilman John Sears expressed dissatisfaction with the design and environinental issues. Councilman Ray Flynn brought up the Tent City issue, in concert with State Representative Mel King, in a statement vowing to "sink the project" if the BRA dic not follow through with assurances that Tent City would be developed. The BRA made a commitment to bulld subsidlzed housing on the site, and indicated that HUD would look favorably on an application for federal funds to make Tent city work (Globe, 4/30/80).

The problem for the developer at this point was project financing. The City submitted the UDAG contingent upon the provision of information pertaining to financing (UIDC, 1980, P.13). The lack of this information resulted in a postponement of HUD review until the next funding period deadline, June 30.

Daring May and June, OIDC devoted its full attention to bringing profect feasibility to a level that would allow for the necessary presentations to permanent lenders. UIDC could not secure the bulk of 1ts financing because of incomplete design development and environmental 
impact studies, unresolved architectural and engineerir wisk, and outstanding permits and approvals from the City (UIDC, 1980, p.13). Again, however, the developer was unable to supply the necessary financing information to HUD by the deadline, and petitioned HUD for another delay, until September 30.

By mid-August, UIDC had secured the financial commitments needed for the UDAG review. Financing for the project is arranged by Morgan Guaranty Trust Company of New York, the First National Bank of Chicago, and Citibank, N.A. of New York. The investment capital is provided for by the above lead banks and the First National Bank of Boston. Security Pacific National Bank of Los Angeles, and Seattle First National Bank (UIDC, 1981). The financial arrangements were written into the UDAG application, which was considered by HUD on September 30, 1980. An administrative compleint was filed on June 5 by several community groups to protest the UDAG application. The complaint, filed with HUD, claimed that: 1) Boston was not eligible for UDAG funds (based on litigation regarding the segregated characteristics of Boston's housing policies); 2) Copley Place did not require a UDAG subsidy (UIDC has assets totaling $\$ 1$ billion); and, 3) negative environmental impacts, and displacement will result from the project (Administr ative Complaint, 1980).

The BRA began preparation of a response to the complaint, and filed a rebuttal on August 11. The response addressed each issue in deta1l, and defended the project as one that would meverage substantial privete investment to the direct and indirect benefit of low-and moderate- 
incone people, especially members of minority groups" (BRA, 1980, p.iv).

At DIDC, the design development process was the summer's activity. By July, 1980, the design was complete, containing the same mix of uses, the same elements, and the same layout as had been defined in the UDAG and the Draft EIR/EIS (note: the Draft EIR/EIS was submitted to the State in February, 1980, and was considered at a publio hearing in March, 1980). The detailed design was a bit larger, however, increasing approzImately $7 \%$ (UIDC, 1980, p.14).

Three separate design reviews were required for final approval. Held during July and August, the reviews were conducted by the BRA, representing the City; the Massachusetts gistorical Comission, holding a 106 review of the development's impact on the abutting South find Historicel District, and the CRC Design Review Subcomittee (DRSC), upon whose recommendation the MTA would rely for their decision, representing the State (OIDC, 1980; p.14).

The DRSC completed review of the desion and made their recommendations to the full CRC and the MTA officials on september 24, 1980. They raised objections concerning several of the architectural features of the project, including the use of large areas of synthetic materials on blank walls, the lack of relation to the surrounding area, and the apparent discouragement of pedestrien use of the complex (Globe, 10/3/80). Other points raised by the DRSC relate to the expected environmentel problems such as high winds and shadows across Copley Square. However, the MTA ignored the DRSC concerns, and gave unqualified approval to the final design (Globe, 10/3/80). 
The BRA gave approval to the schematic desion on September 22, 1980, but reserved final approval on mumerous desim 1ssues... . not. . . fully resolved to date between the City and UIDCn (BRA, 9/22/80). The BRA Iisted nine open design items to be negotiated, and reserved the right to withhold UDAG money until the issues are resolved.

The Massachusetts Historical Commission (MBC) gave qualified approval to the design in the 106 review procedure. The MHC's role in the review is to evaluate the design of Copley Place in relation to the surrounding historic structures (the Boston Public Library, the Trinity Church and the South Fnd brownstones.). The Commission has agreed to the overall design but is involved in an ongoing review of the more detalled design elements as they are amended (Joseph Orphent interview).

With most of the steps either completed or underway, OIDC waited for the UDAG approval. Construction of the project was contingent upon the Federal money to perform the necessary site preparation work. As anticipated, the UDAG was approved on October 2, 1980, clearing one of the last major hurdles for project realization. The announcement of the approval came through Senator Edward Kennedy's office (D-Massachusetts), signaling the largest amount for a single UDAG in the history of the program.

The only matter unresolved was the transfer of land between the city and the MTA. Two parcels of city-owned land were to be transferred in order to enable UIDC to move stuart Street slightly south and enlarge a triengular parcel on which one of the hotels is to be built (Globe, 11/6/80). The city Council gave approval to the land transfer on 
November 5, which allowed UIDC to schedule groundbreaking ceremonles. Councilman Sears, voicing concerns shared by the defunct DRSC, warned that the project did not promote pedestrian access. He had submitted an amendment to $t$ he land transfer legislation requiring that a sidewalk be built along the new stuart street. The amendment also called for reactivization of the DRSC.

The MTA had threatened to revoke the lease and withold the site if the sidewalk were required. The sidewalk would cross at the tumplke exit ramp and would result in traffle problems, according to MTA Chairman Driscoll (Globe, 11/6/80). The renewal of the DaSC was left as en amendment to the land transfer, but the City Council then passed a separate resolution that stated that the citizen design review function had been met. The BRA had met with "concermed citizens" on November 3, 1980 to discuss the design.

One week later, UIDC held the official groundbreaking of Copley Place. On November 13, 1980, over 400 people listened as guestspeakers heralded the historic event. The featured speakers were Thomas Klutanick, Chairman of the Board of UIDC, Governor King, Mayor White, and MTA Chairman Driscoll. Eeference was made to the benefits that would result from Copley Place, including the tax benefits (the $121 \mathrm{~A}$ request had been denied) and the job crestion. The State and local tax revenues will anount to $\$ 27$ million per year, and the payroll for the permanent jobs will be $\$ 96$ million, in 1979 dollars (Weidner interview). The remeining issues that complicate Copley Place are the law- 
suit brought by eight South End residents and the unresolved design elements. Both issues are delaying the transfer of the UDAG money from the Gity to UIDC.

The resolution of the lawsuit is undetermined. U.S. District Court Judge Andrew Cafferty refused to dismiss the case after a motion for summa y judgement was filed by HUD. In so doing, Judge Cafferty stated that HUD failed to establish that it had the "relevant racial and socio-economic information" it needed at the time of the UDAG review (Memorandum, 8/17/81). A trial date has not yet been set, al though a date is expected to be announced sometime in May, 1982.

The unresolved design issues holding the UDAG funds (received by the BRA in May, 1981) were outlined in the preliminary approval of September 22, 1980. Of the nine points stated, five have been resolved (DiLeo interview). The remaining issues concern the blank wall, the design of the housing component, the entrance to the community retail space, and the nature of the plaza on Stuart street. According to Teri Weidner, the design process is expected to be long and involved. The finer detail matters that remain unresolved do not affect the construction. schedule. Construction work is continuing at the copley Place site, giving the impression that UIDC is confident that the outcome of the lawsuit and the design issues will be positive.

The future for Copley Place, after five years of negotiation between all levels of government, community, and private interests, is uncertain. As the process continues, cost estimates have mushroomed from the original estimate of $\$ 295$ million to the current figure of $\$ 400$ million. 
V. Analysis and ronclusion.

The Copley Place project is underway the construction schedule is being followed, and an opening date of 1984 is anticipated. A full evaluation of project success is not possible until completion of the construction phase and start up of operation. However, for the most part, the negotiations process which set the stage for implementation of the project is completed (except for the unresolved design issues). A preliminary assessment of the public sector role in the process can be made.

The state, the first public sector actor/negotiator, had the ultimate card in its hand to leverage and shape the type of private inveestment proposed by UIDC - ownership of the strategically situated land. UIDC could not complete any project without a parcel in a prime location on which to build. From the initial stages of negotiation, the state could threaten to withhold the land in order to design the project to maximum public benefit. The crucial decision to lease the parcel rather than sell guaranteed state leverage up to the signing of a lease agreement. Frank Keefe, in reflecting on the State's role in the negotiating process, emphasized the advantage of state ownership and the notion of leasing the property. He states that, "The economics worked to our advantage. We were able to talk with the developer in terms of phasing the rent payments. As a result of escalating the rent payments over time, the developer did not have to capitalize his purchase of the land ... We were able in the bargaining to say to them, 'Look, you don't have to take down the land from Day One'" (Hollister, 1980, p.53). A mutually beneficial "deal" was worked out. The State and city gained a major, tax producing development; JIIC gained the opportunity to construct an enomiousiy. 
profitable project.

The state completed its role in the negotiations in December of 1978, but the Copley Place groundbreaking did not occur for another 2 years. The public sector actor/negotiator during this second phase was the City of Boston, represented by the BRA. The assessment of the second phase entails the actual implementation of the project (the entering into the construction phase), the financing, and the final design development. What role did the BRA play? How did it choose to approach the negotiating table? How did the BRA become involved?

The City was a pessive participant early in the negotiations. Two reasons exist for this "wait and see" attitude. The first reason is that technically the city was not involved in the process at that point. DIDC needed to secure a percel before continuing with the part of the development process that would involve the City in a more active way the permit approval procedure. The second reason is more political, dealing with personalities and individual loyalties. When UIDC initially approached the State with the idea of Copley Place, they were associated with the Great Bay Company, a development firm started by $\operatorname{Dan}$ Gifford. Gifford formed a joint venture with UIDC to develop Cop'y Place, and acted as their local agent in the early months of the process. Mayor White had dealt with Gifford before, in connection with the Park Pleza fissco. Gifford represented a development firm other than the one chosen, the firm owned by Mort Zuckerman - White's personal friend. White withheld the City's support of Copley Place as long as Gifford 
was involved. On a viait to UIDC's Chicago development, Water Tower Place, White let it be known "that Gifford's connection with the project would not help it secure the necessary approvals from the city" (Hollister, 1980, p.40).

A related factor to the Mayor's initial cold shoulder is found in his friendship with Zuckerman. As mentioned earlier, both the city and the state were sensitive to the fallure of Park Plaza just a couple of years earlier. However, Zuckermen blamed the prospect of Copley Place being built and the state's open-arm attitude toward UIDC for problems he experienced with his Park Pleza proposal. The Copley Place proposal and 1 ts Weatin Hotel represented competition to his development (Hollister, 1980, p.40). White, out of loyalty to his frlend, echoed Zuckerman's view, and kept a distance from Copley Place (Keefe intervlew).

Eowever, when Gifford was no longer associated with the project, and Zuckerman's feelings were sufficiently healed, White authorized more active involvement in the process. According to Keefe, the city sent observers only to the early $\mathrm{CRC}$ meetins as passive representatives of its interests. However, with Gifford gone in early 1978, Robert Ryan, Director of the BPA, became directly involved. At this point, Keefe said that White wented copley place to succeed for the city. Polltically, White had been on the losing end of two major developnents in Boston: the Charlestown Navy Yard project, against which White fought, was Implement anyway; the Park Plaza development, for which White was a vigorous supporter, hed falled. Keefe said, "Copley was to be Kevin's (White's) success." (Kee'fe interview). 
The BRA's active participation began after the MTA signed the Alr Right's Lease with UIDC. With Dukakis administration actors, Keefe and Selvucci, out of the picture (due to the King victory), the only remaining state actor was John Driscoll, Chairman of the MTA. H1s term overlapped the administrations. According to the BRA Project Coordinator of Copley Place, Iucas Diteo, there was a leadership role which Driscoll did not fill. The city fllled the void and took up the leadership role enthusiastically. Ryan, BRA Director, speaks of the agency as "shifting away from its 160 's and $70^{\prime}$ s main role of directing and channeling heavy public investments into the city in order to encourage tax yielding private investment, to a role as manager of the pending private investments, as financial analysts in determining whether the city would even want or need future building investment, and attempting to further strengthen its role as a city planning agency" (Globe, 1/11/81). The BRA was ready to be a manager of Copley Place.

The City came to the negotiating table wanting a number of goals achieved. Primarily, the city wanted revenues and jobs for residents. The City also was looking for hotels to help promote tourism and convention business in Boston. Also, the uniqueness of Copley Place - the mixed-use, innovatively designed structure - was appealing (Lewls interview). The BPA sew the site as berren and underutilized; paying no texes; providing no jobs; offering no housing, shopping or other services. The Copley Place project, with millions of private investnent dollars, would "transform this wasteland into a vibrant urban resource" (BRA, 1980, p.1). 
The BRA saw a great opportunity to realize these objectives.

In order to achieve the goals mentioned above, the City employed the leverage tools available to them - the UDAG and the design review process. The BRA used these to monitor the Copley Place program development for benefits to the City. To facilitate the permit approval processea that were necessary, the BRA provided guidance to UIDC in working with the varlous city agencles (Lewis interview). Rather than throwing up red flags, the BRA exercised a little more cooperation in the process. The priority in approving the development program was apeed to accomodate the developer's schedule - but always with the city's interests. The BRA could have slowed each step, losing direction in a burealcratic quagmire typical of some pubilc-private ventures. The tactic employed instead kept negotiations more open.

Nevertheless, how crucial the presence of the BRA was in the planning of the Copley Place project is open to sane discussion. Keefe, the State Planner who led negotiations up to the lease slening, feels that the City had no significant impact on the shape or form of copley Place (Keefe interview). The critical planning issues were decided before the BRA came into play. Copley Place, "probably the most successful planning project in Boston", according to Keefe, was settled by the state participants.

The only legitimate objective that the city had was "seeing the project through," continued Keefe. The urban design and community issues 
were resolved: the EIR/IIS process was at the state level (until federal funds became involved, at which time a federal EIS was necessary), and the CRC was a state-sponsered entity. The CRC function ended in May 1979 in accordance with their contract with the MTA.

Keefe sald that in the beginning of the process, there was no flek regarding the development. The problems between the public and private interests came later with the inclusion of Tent City as an issue and the UDAG application. However, politically aware, the state tried "to make it Kevin's (White's) project from the beginning, so he wouldn't sabotage it later on" (Keefe interview). The BRA, riding on the coattails of the state's planning and negotiation, was able to embrace a success story and appear to wake it 1 ts own, continued Keefe.

Whether or not Keefe is correct in his opinions of the BRA's role in shaping Copley Place, the BRA role as UDAG applicant cannot be disregarded. The BRA was able to negotiate with UID over soclal issues of employment opportunity and housing. As presented earlier, White was clesr during the UDAG talks that he stood behind a policy of benefits for residents. The UDAG money was necessary for project completion, and the BRA used that fact as a lever in the beginning of terms.

The UDAG application process gave the city the opportunity to achieve its goals for Boston residents. W1th public financial subsidy, public benefit must follow. The UDAG program requires thet a project benefits low income groups, and the application provided both a way to secure more mogs - and more importantly, a way to finance future nelghborhood investment. The city used the UDAG to go beyond the immediate boundarles of 
the copley Plase rite, as the benefits resulting from the project will be city-wide. The city has documented, with independent consulting studies to confirm, that any negative impacts resulting from the project are outweighed by the positive. To mitigate the negative impacts, the city intends to utilize funds created from the UDAG itself, accrued from the UIDC loan paybeck.

The presence of the payback fund is a key to EUD's approval of the UDAG, says Frank Smizik, lawyer for the South Fnd residents suing HUD. He feels that HUD was not convinced that UIDC needed the money for project feasibility, but that a payback of $\$ 15$ million of the UDAG, with interest, seemed to justify the proposal (Smizik interview). The leverage of private monies with the public dollars was a $15: 1$ ratio at the time of the application. UDAG guidelines specify only a 5: or 6:1 ratio as necessary. The tremendous difference could be indicative of UIDC not really needing such a comparatively small amount, or it could be indicative of needing that money as a seed to leverage the rewrinder of private financing. In any event, the payback was a sweetner in the decision - for the BRA as well. The prospect of $\$ 42$ million over the next 25 odd years is strone incentive to apply for a federal grant. The BRA realizes, along with everyone else, that the future of massive federal subsidy is uncertain with the Reagan administration and the economic downturn. The Copley Place UDAG provides public investment capital for the future so that Boston does not have to rely exclusively on unpredictable year to year support.

The BRA will have discretion with the Neighborhood Developwent Fund. 
The good intentions detalled in the Copley Place UDAG defense may or not come to realization. Smizik, in outlining justification for his client's case, fears that the fund will be used to finance more job creation for the professional (Smizik interview). The BRA used "fallacious reasoning" and disregarded some of "the facts and figures" in their defense of the UDAG. In order to promote jobs, the BRA glossed over the real housing issues such as displacement. He feels that the same will occur in the future when considering projects to fund. The problem is based upon the fact that the BRA has contact with developers rather than the community (Smizik interviev).

Resldents of the South End impact areas voiced their opinion of the IIDAG at the public hearings held during the application approval process. Kenneth Campbell, resident and member of the Ellis Neighborhood Association, asked "whether we should subsidize a profit-making commercial development in order that it can build a very large project that will help disintegrate the multi-racial, multi-class, multi-ethnic neighborhood" (Testimony, 1979, p.38). Bill Abbott, resident, stated that giving $\$ 18.8$ million to this project is "an example of socialism for the rich and an example of nothing for everybody else" (Testimony. 1979, p. 164).

These allegations are not at this point proven. The views held by Smizik and the South End residents he represents will be considered in a court of law. Yet, the fact that the BRA used the UDAG as a means to create the neighborhood fund is undisputed. The effectiveness of the fund in overcoming what the BRA refers to as "natural demographic changes" 
rather then displacement, will be determined at some future date (BRA, 1980, p.11). A judgement now would be premature.

The use of the UDAG as a leveraging tool for jobs was a second example of bargaining for public benefit. Disregarding for a moment that strong affirmative action provisions for construction were already Included in the MTA lease, the city did attempt to extend the provisions to perranent Jobs. The Boston Globe editorialized that nit is a sign of the city's strength that it is able to negotiate with a major developer on allied questions relating to the creation of job opportunties for Boston residents" (Globe, 4/30/80). The White administration was successful in a 50\% resident job agreement with a high technology firm Teradyne, Inc. moving into Boston (with the leverage of a federal grant) earlier In 1980. The Copley Place agreement would be comercial rather than industrial developwent, and would set a precedent for resident-jobs agreement for future development of that type. -

Unfortunately, the city was unable to secure guaranteed resident jobs. The agreement settled upon in the UDAG outlines goals rather than required quotas. The permanent job provisions are vague. For one resident, Copley Place is no different that other developments that promise jobs to the nelghborhood: "They said jobs. They sald jobs - the Prudential. You big guys been talkin' about jobs for so long ain't nobody gonna believe you anymore" (UDAG Testimony, 1979, p.150).

- The jobs issue was, as Weidner of UIDC referred to $1 t$, a "hang up with the city." She holds that the affirmative action guidelines in the 
MTA lease, for construction, are unprecedented, and in fact exceeded those called for by the city. The MTA lease requires $20 \%$ jobs for minorities during construction, while the UDAG agreements merely set goals. Compliance with the reouirements is monitored by the MTA; the attainment of the goals set by the city would be monitored by a committee of esteblished contractor and union interests. The Boston Jobs Coelition, the principal advocate of resident-jobs, is excluded from the oversight committee. Therefore, the committee's composition is questionable.

Keefe, in reflecting on the MTA lease said that the affimative action requirements are "revolutionary" (Keefe interview). The lease terms provide for a recruttment office and review mechanism. He feels that the city tried to make the jobs agreements their own, and attmepted to retrace the state's steps to replicate an agreement for the c1ty's personal credit. Nevertheless, jobs will be created in great number, and if the goals are met, they will aggregate 2034 for low and moderate income, 1261 for CETA - eligibles, and 1512 for minorities, as specified in the UDAG agreement (signed by Yayor White $2 / 24 / 81$ ).

Peralding the Copley Place development, Mayor White claimed that "the terms of this grant provide a national model for building a financial bridge between the downtown and the neighborhood. This model assures that future downtown development will benefit this city's nelghborhoods, both directly in terms of jobs for our people and indirectly through the money which will be funnelled into the Neighborhood Development Fund" (Globe, 4/10/80). To the outside observer, the project appears to be 
successful. As opposed to Park Plaza, the city reached an agreement with the developer in just two years. For the most part, the project succeeded in accomodating the conflicting goals of numerous participants in the process. The design components include low-income housing and community retail space; the construction phase guarantees jobs for minorities; goals have been set to target permenent jobs to residents; over $\$ 40$ million will be returned to the city through the loan payback; the city will recelve at least $\$ 7$ million annually in tex revenues; and finally, OIDC w11l own one of the most unique downtown development projects in the country.

The "vibrant urban resource" being created at Copley Place will have both positive and negative impacts. Not everyone will be satisfled with the end result, but the benefits for the city will extend beyond the bounderies of the site. That a developemnt of its size would be ventured In Boston is a credit to the ability of the city to accept and work with the private aector. The outlook for Boston's building expansion is good; according to a Globe article, the city is nin the midst of a $\$ 1$ billion construction boom which will extend into 1982 and 1983 and beyond" (Globe, 1/11/81). The city, working though the BRA, has comitted itsaf to approving development based on what it thas to offer in terms of maximum job opportunities for Boston residents and In terms of minimizing local public investment, and in gaining agreements with builders to conform to city planning atrategles aimed at channeling bullding investment into those areas the planners feel need the benefits of new construction, even 
though the levelopers would rather build in the downtown financial area only" (Globe, 1/11/81).

The problem for the city and the BRA is to make certain that these "city planning strategies" do not ignore the vitality of the neighborhocis. The rhetoric of a financial bridge between the downtown and the neighbor oods must ass the press conference stage and move into implementation. The Neighorhood Development Fund and jobs created by Copley Place provide real economic justification for pursuing a downtown development policy.

The key to the success of the downtown building boom and the massive infusion of private dollars is a mental climate that respects private werl th and attracts it into projects that will benefit the people of Boston. As said by John Ryan, former member of the "Boston Planning Board," (sic), "The human links that this development (Copley Place) proposes and that this development can accomplish for linking neighborhoods is a very significant part of joining important neighborhoods in Boston. This project will close scars left by construction of the Turnpike Extension 15 years ago and will provide the city with tax revemue and economic activity where neither exists now. The role of the city is properly in place here in supporting investment both on a city and the state and federal level. . to benefit the city on the whole" (Testimony, 1979, p.88).

The benefits gained from any project as massive as Copley Flace; the impacts felt by the numbers of people nearby; the phiysical al teration 
to the geographic area - these circumstances will be far reaching for Boston and the metropolitan axea. For as many persons who support Copley Place, there are as many who discount its value. "Large scale developrent is a two-edged sword" (Globe, 10/15/80). A judgement as to the absolute success or failure of Copley Place and the role of the public sector in the implementation of the project is reserved for analysis at another time. But what can be learned is the complexity of public-private development ventures, and the availability of leveraging tools to guide and shape investment to public benefit.

Economic growth, devoid of economic derelopment policies, does not help the community. Rowever, when a public agency intervenes to shape and expand its scope to embrace a brosder social context, as the BRA did with Copley Place, urban economic policy implementation begins to dull tine sharp edge of the developrent sword. The innovative techniquea exercised by the BRA may or may not prove to be the most beneficlal to each resident of Boston, but they go a long way in the attempt to ensure that victims of economic growth are not too badly injured. 
On April 18, the Massachusetts Turnpike Authorlty entered into a six-month Meworandum of Understanding (M.O.U.) with Great Bay Co. and Urban Investment and Deivvelopment Company (UIDC) during which Great Bay Co. and UIDC will ngage in eng1neerIng and market analyses and the Turnpike Authority will refuse to negotiate or lease its Copley Square land and air rights to any other party. A 60-jay period beyond the six months is provided in which Great Bay Co., UIDC, and the Tumpike Autherity must execute an option agreement. If no such agreement is reached, the obligations of the MOU terminate.

In order to guarantee that the best interests of the Commonealth, City, and the adfacent neighborhoods are served, the Governor has asked that the Developrient Cabinet take the lead role during the slx-month analysis in cvaluating envirnnmental constralnts and commity desires. The office of State Planning will coordinate the involvement of the Development Cabinet to ensure that the views and values of neighborhood groups and city officials are integrated into both design and environmental studies. The Tumpike Authority will enter into concracts for consultant services to be avallable to the Development Cabinet and tie Citizens Advisory Gruup on design, environmental, and community issues.

At the end of six months, everyone will have a full understanding of the constraints and opportunities at Copley Square, and a decision can be made by buth the developer and the state and the city public sector agencies as to whether it makes sense to proceed into an option.

This decision-making process is reflective of the lesire of state and city government to work directly and cooperatively with an interested developer of proven record on a ste with significant development impcdiments while ensuring full and active participation by public agencies and community groups to promote an appropriate and acceptable project.

FRANK KEEFE, DIRECTOR

OFFICE OF STATE PLANNING 
Citizens' Review Committee

List of Meetings

$\underline{1977}$

Information and Concerns

May 19: Orientation

June 2: Legal and Traffic Issues

June 9: Physical Constraints

June is: Development Economics, Business Impact, and

June 23: Scheduling and Summary

Traffic Working Group

June 30: Interim Report Distribution

Recommendation Development

July 7: . Community Economic Development

July 13: $\quad$ St. Botolph Working Group

July 14: $\quad$ Impact on Back Bay Busineśses

July 15: Working Group on Business Opportunities

July 26: Working Group on Jobs and Training

July 28: $\quad$ Preliminary Physical Design Presentation

July 29: Working Group on Business Opportunities

Augus t 4: Neighborhood Stabilization

August 12: Working Group on Busines's Opportunities and Jobs

August 18: Draft Recommendation's and Revised Schematic

Design

September 8: Comments and Revisions of Draft submitted to CRC

September 16: Discussion of Revisions

September 22: Recommendation submitted to State, MBTA, developer

1978

$\begin{array}{ll}\text { June 15: } & \text { Introductory Meeting } \\ \text { July 6: } & \text { Environmental Impact Review } \\ \text { July 13: } & \text { Pedestrian and Design Issues } \\ \text { July 20: } & \text { Economic impact } \\ \text { July 26: } & \text { Traffic Impact } \\ \text { August 3: } & \text { Social Impact } \\ \text { August 10: } & \text { Summary Meeting and Recommendations }\end{array}$


February 22: Review of necessity for Copley Place re-study

May 24:

May 31:

June 14:

June 27:

July 12:

August 2:

August 9:

August 16 :

August 30 :

September 6 :

September 20:

November 8 :

November 12:

November 15:
General meeting to start new round of CRC meetings (UIDC handout \#I)

Review of new design and program (UIDC handout \#2)

Review of public benefits and public funding requirements (UIDC handout \#3)

Transportation planning issues - session 1,

Methodologies (UIDC handout \#4)

Environmental issues - session 1. Outline of proposed EIR/EIS (UIDC handout \#5)

Review of scope of services for retail and housing impact studies (No handout for meeting \#6)

Transportation Planning issues - session II ( UICC handout \#7)

Design review and housing review (No handout for meeting \#8)

Environmental issues - session 11. Geology, energy conservation, noise, historic properties, wind, air quality (UIDC handout \#9)

Environmental issues - session 111. Traffic and air quality (UIDC handout \#10)

Workshop on housing impact report. (ERA handout no UIDC handout)

Meeting on Public Approvals Process

Meeting on Retail Impact Study

Meeting on Housing Impact Study

1980
March 6: EIR/EIS Review

April 14: UDAG Review

July 17:

September 24: Design Review Subcommittee report to the CRC 


\section{EXECUTIVE SUMMARY}

\section{Introduction}

Copley Place is an exemplary project which deserves HUD's support through the Urban Development Action Grant Program. At present the site is a barren and underutilized turnpike interchange. It pays no taxes, provides no jobs, offers no housing, shopping or other services. The proposed project, through the infusion of $\$ 300$ million in private funds, will transform this wasteland into a vibrant urban resource. When it is completed, it will provide more than 6,000 permanent jobs, many to presently unemployed Boston residents, as well as millions of dollars in taxes to the City and State. It will house 100 families of mixed-income and races and will serve as a unifying force for neighborhoods that have been separated by physical barriers for over a hundred years.

The planning process for Copley Place has also been exemplary. The developer has worked with community groups, public agencies and individuals over a three year period to produce a project which is responsive to the concerns of the surrounding neighborhoods. As a result of this process a number of significant changes were made in the project proposal.

Copley Place will be an asset to the City as a whole and to the surrounding neighborhoods in particular. Contrary to the assertions contained in the Administrative Complaint, Copley Place will have at most a minimal effect upon housing in the surrounding neighborhoods. The changes taking place in these neighborhoods are due to a variety of demographic forces, some of which are national in scope. The City believes that an objective evaluation of all aspects of this project will show conclusively that Copley Place should receive UDAG funding.

II. Boston is An Eligible Applicant for UDAG Funds

The City meets all criteria for UDAG eligibility.

(a) It meets the minimum standards of physical and economic distress.

(b) It has an outstanding record in providing housing for persons of lowand moderate-income.

(c) It has demonstrated results in providing equal opportunity for low- and moderate-income persons and members of minority groups. In particular, the City is in substantial compliance with the conditions on its most recent Community Development Block Grant.

III. UIDC Does Require UDAG Funds to Construct Copley Place

A UDAG grant in the amount of $\$ 19,724,000$ has been determined to be warranted by the Boston Redevelopment Authority's review of the Copley Place project. The City recognizes the large up-front costs inherent in developing this site which have succecded in keeping this parcel vacant for the past two decades. These activities add greatly to the construction costs of the develop- 
ment without adding directly to the cash flow of the project. To confirm its analysis, the BRA retained an independent consultant which has advised it that the project sponsor's cost estimates and income projections are reasonable and that, based on these estimates, the project would not reach a fair level of return without such a UDAG investment.

Contrary to the complainant's allegation, the developer was exploring funding sources for public improvement type activities in the Spring of 1978 and actively addressing public assistance for the development in the Fall of that year.

The ratio of private investment to UDAG funds will be 15 to 1 , far exceeding HUD guidelin. .

IV. The Boston City Council Did Act Upon the Application With Sufficient . Information to Evaluate the Project's Impact Upon the City and Its Residents

The UDAG application meets all HUD requirements for public review and approval by the local governing body, which in fact voted unanimously to submit the application. More important, the planning of the project involved unprecedented public review from the very beginning. Over 40 Citizen Review Committee meetings were held over three years with neighborhood groups to review the project and obtain their input. As a result of these meetings major changes were made in many aspects of the project and significant affirmative action provisions achieved.

V. Copley Place Will Not Have A Negative Impact On the Special Problems Of Low - and Moderate-Income and Minority Pcople

The overall impact of Copley Place will be positive through the provision of jobs and housing for low- and moderate-income people, taxes to support City services, and loan repayments by the developer that will support neighborhood development projects. While there may be modest impacts in terms of increased demand for housing which may contribute to displacement, this effect is expected to be minimal and the City has policies which will be able to mitigate even these forces.

\section{A. Housing and Displacement}

1. The Administrative Complaint confuses natural demographic changes with displacement.

2. The City is meeting its obligations to minimize the effects of any displacement which may occur.

3. Displacement is a complex phenomenon, not well understood. What is happening in the neighborhoods surrounding the Copley Place site is the result of many different factors, some of them national in scope, others more localized. These neighborhoods were in a serious state of physical and economic distress for decades ( $c f$ extensive documentation submitted to HUD to qualify the South End, Fenway and South Cove as urban renewal areas) and have only recently begun to show signs of renewed vigor. Thanks to significant expenditure by the Federal, State and local governments, the most serious physical blight has been eliminated, public works and 
facilities improved, and over 6,200 units of new or substantially rehabilitated housing has been provided in the impact area for lowand moderate-income people. A recent survey of the South End neighborhood indicates overwhelming approval by the residents for the changes which have taken place and a hope that revitalization will continue. Displacement as an issue was articulated by only $3 \%$ of the population.

4. There is no evidence that Copley Place will cause any displacement, though there will certainly be some additional demand for housing caused by the project's employees. The best estimates are that this impact will be small in the immediate area (within a 15-minute walk) an.. so dispersed outside that area as to be unmeasurable. Many of the jobs generated by the project will go to present residents of the area or the City of Boston, including people who are presently unemployed, underemployed, or not in the labor market. The experience with other major developments in this area - which did have a significant effect on housing demand - does not apply today. Those developments took place at a time when housing prices in the impact area were relatively low and constituted a major inducement to immigration. This is no longer the case.

5. The South End, the area most frequently cited in the Administrative Complaint, has been subject to a great many changes in recent decades. It is not at all clear that what is happening there could be called displacement. It certainly is clear that throughout the period when displacement was allegedly taking place, large numbers of Blacks and Hispanics were moving into the area. Since this is not a phenomenon normally associated with displacement, it suggests that a more complex process is underway and that any generalizations about the impact of Copley Place are subject to qualifications.

6. Should there be any displacement as a result of Copley Place, the City does already have programs in place to address this problem. There already exist in the surrounding neighborhoods 6,200 units of new or substantially rehabilitated subsidized housing. The existence of this housing guarantees that the impact area will remain economically and racially mixed. Furthermore, an additional 1,500 subsidized housing units are presently in various stages of development and will be available to any families who may be displaced. Close to 800 market rate units are also being developed and will help to absorb any demand in the impact area caused by Copley Place. The City also has rent control and condominium conversion ordinances which will help to mitigate the effect of market forces on low- and moderate-income tenants.

\section{B. The Jobs Policy}

The City has adopted strong affirmative action provisions for both construction and.permanent jobs generated by Copley Place. The requirements for construction hiring include enforcement procedures which provide for final review by an independent third party. To further ensure compliance with these requirements, the City will make referrals from its own training programs and from those of neighborhood based organizations. A placement office will be established 
on-site for the hiring of permanent employees and the developer will report on a quarterly basis to the Mayor and City Council on the number of residents working in the project.

\section{Copley Place Will Further Equal Opportunity}

As noted above, strong affirmative action requirements will ensure that lowand moderate-income individuals, especially members of minority groups, will benefit from the economic activity generated by the project. There is, on the other hand, no evidence to indicate that minorities will suffer disproportionately from any potential impacts of the project. Nevertheless, any minorities who were to be displaced would have access to a wide range of housing options both existing stock and anticipated new developments - both within their present neighborhoods and in the rest of Boston.

\section{Environmental Planning Is Proceeding Without Substantial Problems}

The environmental review process for Copley Place is expected to be completed in a timely fashion. Draft responses to $95 \%$ of the comments received on the draft EIS/EIR have already been prepared and the final EIS/EIR is expected to be submitted for review in September, with completion of the total process in October of this year.

The project is in compliance with all applicable energy conservation requirements and there is no reason to believe that adequate energy will not be available.

The shadows cast by the project will have only a minimal effect on Copley Square compared to those cost by existing development.

The traffic and parking impact studies carried out for the draft EIS/EIR follow accepted principles and indicate only minimal impact, especially in view of improved transit accessibility and the City's commitment to a resident sticker parking program.

VIII. Conclusion

The City of Boston has prepared a detailed response to each point raised in the Administrative Complaint. These responses have been based on HUD regulations, the City's performance, and the facts of this situation. An unbiased appraisal of the case would clearly recognize the validity of the City's UDAG application for Copley Place. In the final analysis this position rests on the basic premise of the UDAG program. Copley Place is a project by which Federal funds will leverage substantial private investment to the direct and indirect benefit of low- and moderate-income people, especially members of minority groups. Under these circumstance, HUD will best fulfill its mandate by approving the City's application for UDAG funding. Copley Place deserves HUD's support. 
FACT SHEET - COPLEY PLACE

DEIEIOPER: $\quad$ Urban Investment and Development Co. of Chicago, a subsidiary of Aetna Life \& Casualty.

SITE:

9.5 acre land and air rights in Boston's Back Bay with direct access to and from the Ilassachusetts Turnpike, the 'BTTA's Orange Line (under construction), AMTRAK and the Boston and llaine Railroad.

PROJECT COMPO:NEVTS: -- An 804-room liestin luxury hote1.

- -A 1,145 Varrjott convention-style hotel.

-- 8\$5,000 square feet of comnercial office space.

- A 385,000 square foot retail center -. which includes 100,000 square foot Veiman-yarcus specialty department store and a 5j,000 square foot Bonwit Teller -- with shops, restaurants, cinemas and community-oriented retail space.

-- 100 mixed-income residential units.

-- 1,432 parking spaces.

PROJECT COAPLETED: $\quad$ 1983-1984

CONSTRUCTION COST: $\quad \$ 400,000,000$

FINANCING ARRANGED BY: Morgan Guaranty Trust Company of New York

The First National Bank of Chicago

Citicorp Real Estate, Inc.

FINALICING PARTICIPANTS: The First National Bank of Boston

Security Pacific National Bank

Seattle-First National Bank

U.S. Department of Housing and Urban Development

WESTIN HOTEL

ARCHITECT:

CONTRACTOR:

The Architects Collaborative Inc., of Cambridge, MA

Turner Construction Company, of New York, NY

RETAIL/OFFICE

ARCHITECT:

CONTRACTOR:

The Architects Collaborative Inc, of Cambridge, MA

Perini Corporation, of Framingham, $2 \mathrm{AA}$ 


\section{FOR RELEASE: At Will}

\section{COPLEY \\ PLACE}

\section{CONTACT: Teri F. Weidner}

-- COPLEY PLACE --

\section{MULTI-MILLION DOLLAR DEVELOPMENT FORETELLS}

NEW LANDMEARK IN BOSTON

BOSTON -- Copley Place, at $\$ 400$ million the largest mixed-use development in Boston and one of the most ambitious currently underway nationwide, is well on its way to becoming the newest landmark in this history-making city.

It was November 13, 1980, when Urban Investment and Development Co. of Chicago, a subsidiary of Aetna Life \& Casualty, broke ground for Copley Place, culminating over four years of pre-construction project planning. "In the first year after groundbreaking, we have seen rapid construction progress, substantial leasing activity for both the office and retail space, the closing of project financing commitments, and completion of architectural and interior design planning for each project component," said Kenneth A. Himme1, senior vice president and project manager. "Hundreds of construction workers have been employed on the site, and their numbers will expand to nearly 1,000 next year."

\section{THE PROJECT COMPONENTS}

When fully operational in 1984, Copley Plàce will include two major hotels -- the 804-room delixe Westin Hotel-Copley Place, Boston, and a 1145room convention-style Marriott Hotel. A 385,000 square foot retail mall will feature a two-level gallery of shops, a unique collection of restaurants, and a nine-screen Sack cinema complex. Retail anchors will be the first Yeiman-1'arcus 
Vew Landmark in Boston -2-

specialty department store in New England and Bonwit Teller. The project will also include four office buildings with a total of 845,000 square feet of Class $A$ office space that surrounds a nine-story central Atrium, 100 mixed-income residential units, and indoor parking for 1,432 cars.

Unlike any other major retail center in Boston and New England, Copley Place will offer shopp 2 rs an "inside street," two levels of shops and restaurants in an interior landscaped setting that will reflect the materials and textures of Boston's historic Back Bay. Like architect Frederick Law Olmsted's famed Emerald Necklace concept for linking Boston proper with parks and thoroughfares, the Atrium space in Copley Place will be landscaped with seasonal flowers, shrubs and trees, designed to provide a year-round atmosphere encouraging walking and browsing. A multi-story water sculpture will provide the centerpiece of the Atrium. FINANCING

Copley Place holds the distinction of being awarded 18.8 million from the U.S. Department of Housing and Urban Development, the largest Urban Development Action Grant (UDAG) ever. The UDAG program was begun during the Carter administration to encourage investment of private capital in urban centers. The City of Boston will administer the Copley Place UDAG, \$15.5 million of which is a $10 a n$, i) the remainder a grant. Interest from Urban's repayment of the loan portion to the City over the next 27 years will be earmarked for Bóston's Neighborhood Development Loan Bank, creating a unique fund of $\$ 42$ million for improvements to nearby neighborhoods.

More than $\$ 350$ million in private financing for the complex will be provided via three separate loans. Financing was arranged by Morgan Guaranty Trust Company of New York, The First National Bank of Chicago and Citibank, N.A. of New York. 
lew Landmark in Boston -3-

These lead banks will be joined by three others, The First National Bank of Boston, Security Pacific National Bank, Los Angeles, and Seattle-First National Bank, in providing financing.

SITE COPIEXITY

The development is being built on a 9.5 acre air rights site adjacent to Boston's Cople, Square, an historic focal point of commercial and residential activity. The site, and air rights above it, are being leased to Urban from the Massachusetts Turnpike Authority which owns the property.

Cleared in the late 1950's to make way for the Massachusetts Turnpike Extension, the land today includes the major Boston interchange of the Vassachusetts Turnpike, railbeds for Amtrak and Conrail, and the Orange Line of Boston's rapid transit service (presently undergoing relocation). These activities will continue to occur uninterrupted beneath the completed copley Place complex. Three major city thoroughfares also border the site. Comprehensive roadway redesign, relocation of electric, gas, telephone and water lines were necessary to prepare the cumplex site for construction. PUBLIC INVOLVEEET

A public design review process, unprecedented in Boston history, and possibly nationwide, has involved hundreds of citizens representing commercial and residential communities surrounding the site. The State and Urban agreed at the project's outset to invite neighborhood associations, advocacy groups and several government agencies to participate actively in the planning process to maximize commuity benefits and enhance the pre-development review of all project impacts on the neighborhoods. 
New Landmark in Boston -4-

Over 150 presentations on Copley Place were made by the developer to involved groups. A unique Citizens Review Committee (CRC) was formed to identify design, environmental and other cormunity concerns, and to develop guideline recommendations for the project plans. A reorganized group, known as the Design Advisory Group (DAG), still neets regularly to follow progress and architectural development of the project.

\section{PUBLIC BENEFITS}

Copley Place has already provided hundreds of construction jobs to Bostonians and area residents. Over 1,000 workers will have been employed in construction upon completion. Copley Place will then mean 6,500 new, permanent jobs for the city. Affirmative action agreements are the most comprehensive in the country for private development, including goals for Boston residents and residents of neighborhoods adjoining the site.

Covering the Turnpike, the project will rejoin the Back Bay and

South End neighborhoods that have been divided by Turnpike ramps and railroad tracks for over a decade. The stores, hotels, restaurants and offices located inside Copley Place will directly or indirectly provide an estimated $\$ 27$ million annually in City and State taxes. The Westin Hotel-Copley Place, Boston and the Marriott Hotel will attract sought-after convention business and tourist income, while Nejman-Marcus and other top scale retailers will create the most attractive shopping environment in the city and metropolitan region.

\section{EASILY ACCESSIBLE LOCATION}

Copley Place will be easily accessible to motorists, pedestrians, and visitors to Boston. Logan International Airport, Government Center, the Financial District and Downtown Boston are only minutes away. Motorists on the Turnpike can exit 
New Landmark in Boston -5-

directly at the Copley Square interchange. The Turnpike provides a direct link with local primary arterial roads and the Interstate highway system.

Because all iurnpike activity will be under a deck cover, the area will be re-opened to safe pedestrian access. Copley Place will be linked to the Prudential Center with a glass pedestrian-only bridge, and will jojn the Prudential with the John Hancock office tower. Additionally, the project will directly link Copley Square with Veiman-Yarcus, Saks Fifth trenue and Lord \& Taylor.

The new Back Bay Station, under construction across Dartmouth Street from Copley Place, will be utilized by some 55,000 rail passengers daily. The project will also be accessible via !lassachusetts Bay Transit tuthority buses and rapid service trains.

LEASING

Retail leasing agent for the project is Strouse-Greenberg and Co. (617-5234080) and Ryan, Elliot and Company, Inc. $(617-537-8220)$ is exclusive agent for the office component.

ABOUT URBAY

Urban Investment and Development Co., a subsidiary of Aetna Life \& Casualty, , is one of the nation's largest producers of quality improved property. At the close of 1981, Urban had more than \$1 billion in assets withoperations in 1o states. The company develops and orns office buildings, mixed-use structures, shopping centers, planned commmities, luxury hotels, and other commercial and industrial properties. The Chicago-based company has offices in Boston, Denver, Hartford, Houston, Philadelphia and Seattle.

021182 


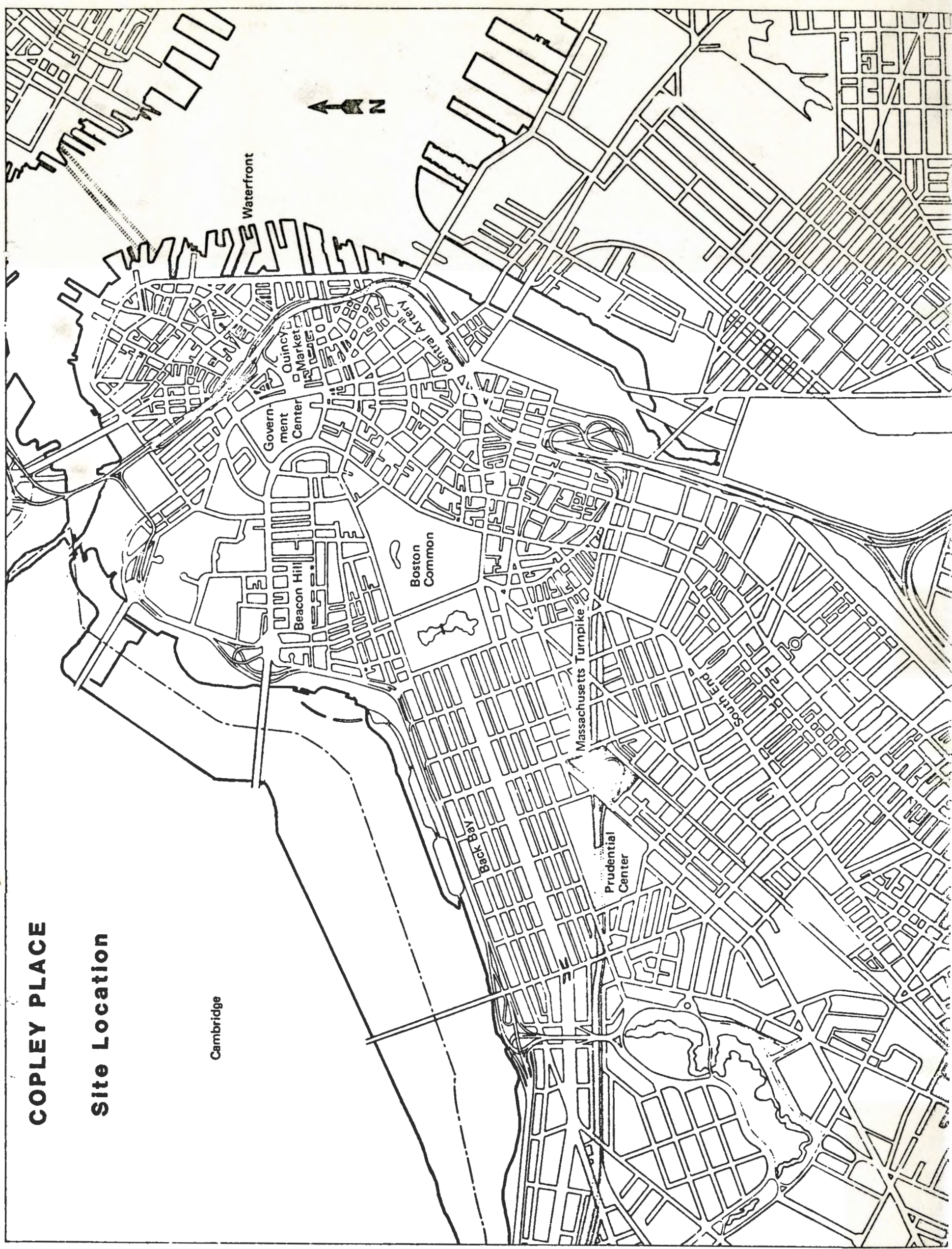




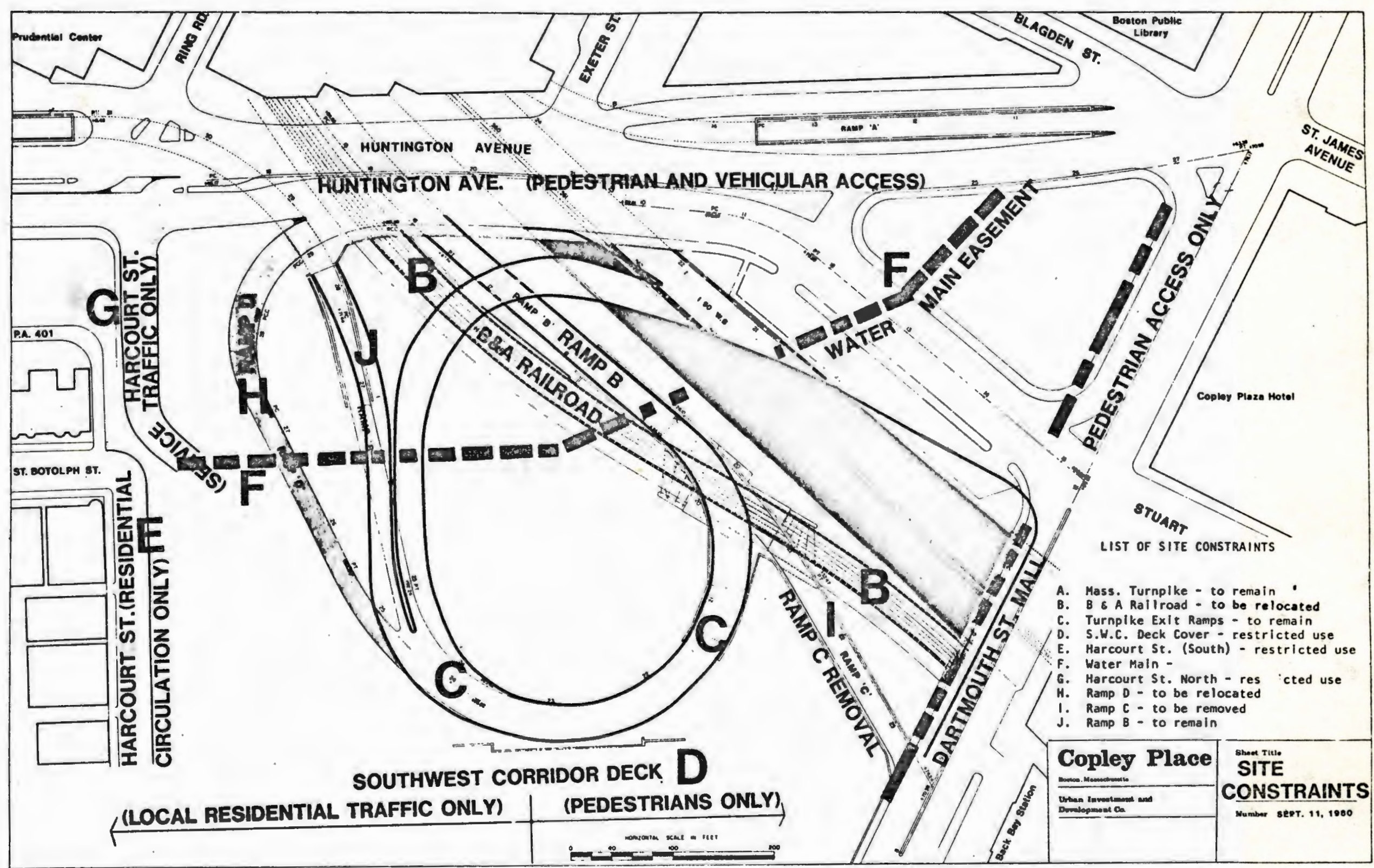




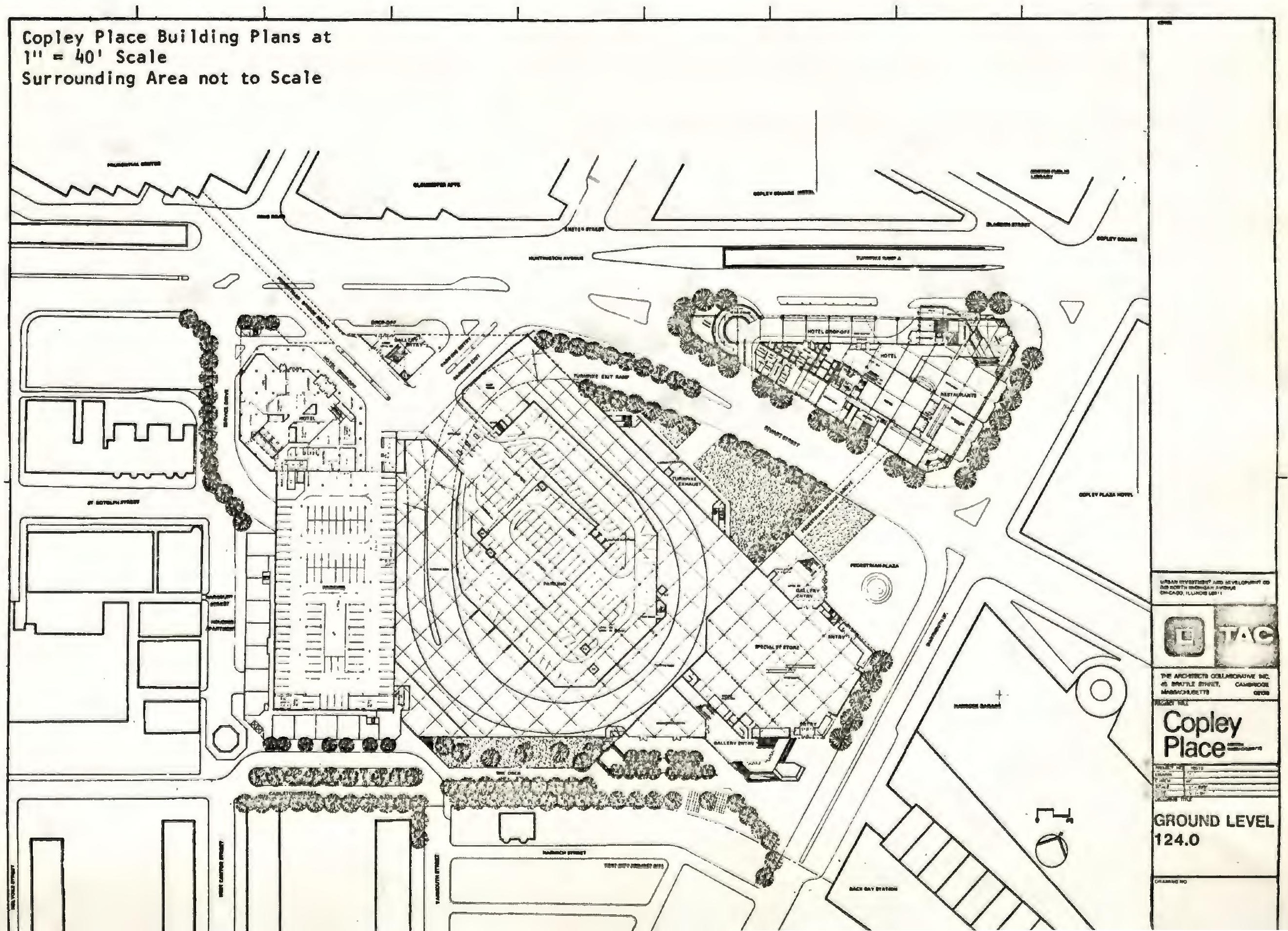



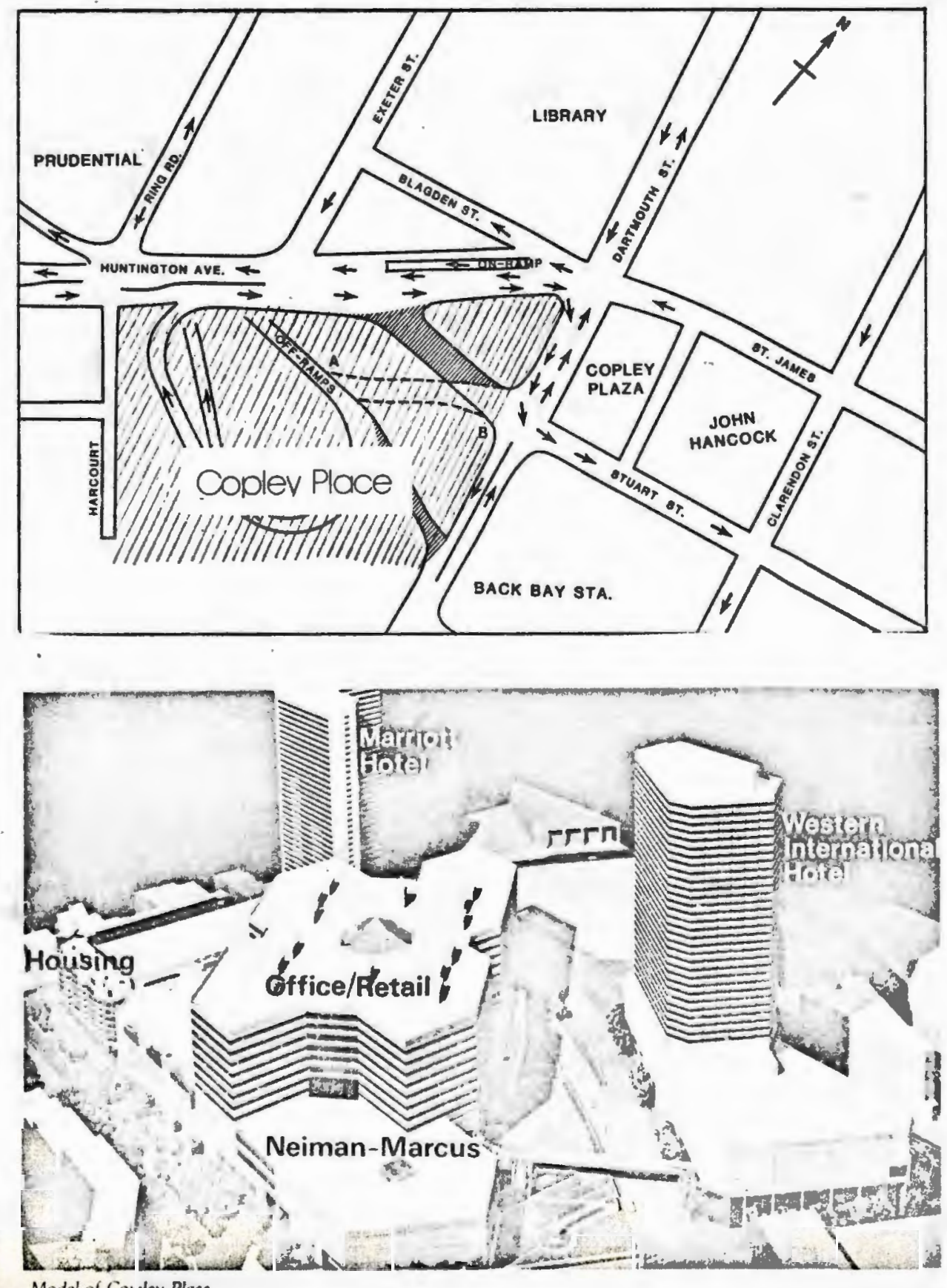

\begin{tabular}{|c|c|c|}
\hline Copley Plare Program & $\begin{array}{l}\text { Gross } \\
\text { Building } \\
\text { Area, } \\
\text { s.f. } \\
\end{array}$ & $\begin{array}{l}\text { Retail/ } \\
\text { Office } \\
\text { Rentable } \\
\text { Area, s.f. }\end{array}$ \\
\hline \multicolumn{3}{|l|}{$\begin{array}{l}\text { Western International } \\
\text { Hotel }\end{array}$} \\
\hline Luxury hotel, 781 rooms & 747,260 & \\
\hline $\begin{array}{l}\text { Parking. } 275 \text { spaces } \\
\text { Mariott Hotel }\end{array}$ & & \\
\hline $\begin{array}{l}\text { Convention hotel, } 1,008 \\
\text { rooms }\end{array}$ & 804,310 & \\
\hline $\begin{array}{l}\text { Extensive meeting } \\
\text { facilities }\end{array}$ & & \\
\hline Neiman-Marcus & 96,090 & 96,090 \\
\hline Retail Mall Shops & 250,420 & 250,420 \\
\hline Community Retail Shops & 8,000 & 8,000 \\
\hline $\begin{array}{l}\text { Cinemas } \\
\text { Service Level, Mall, }\end{array}$ & 16,000 & 16,000 \\
\hline $\begin{array}{l}\text { Circulation. Service } \\
\text { Corridors, Mechanical }\end{array}$ & 150 & \\
\hline Office & 771,400 & 699,940 \\
\hline $\begin{array}{l}\text { Housing } \\
100 \text { Units } \\
\text { Parking }\end{array}$ & 85,000 & \\
\hline $\begin{array}{l}\text { Retail, Office, and } \\
\text { Marriott Hotel }\end{array}$ & & \\
\hline 1,157 spaces & 404,920 & \\
\hline Total Area & $3,434,060$ & \\
\hline
\end{tabular}




\section{Bibliography}

Public documents:

Amended and Restated Lease: Massachusetts Turmpike Authority to UIDC, Boston, liass., 1/31/80.

Copley Place: Urban Development Action Grant Agreement, J.S. Dept. of Housing and Jrban Development, 1/19/81.

Copley Place: Urban Development Action Grant Application, City of Boston, $4 / 30 / 80$.

Lease: Messachusetts Tumpike Authority to UIDC, Boston, Mass., 12/22/78.

Response to Administrative Complaint, Boston Redevelopment Authority, $8 / 11 / 80$.

Testimony from 11/19/79 JDAG Hearing, Office of Public Service, City of Boston, 11/19/79.

Other:

Bor t, Allan, "Promoting Real Eastate Development", Public Management, 9/79.

Copley Place Design Review Agreement between the BRA and UIDC, Boston, Mass. 9/22/80.

Copley Place Final Recomendations, CRC, 9/22/77.

Copley Place Housing Impact Study, Economic Research Assoclates, for the $\mathrm{BRA}, 12 / 79$.

Copley Place Project Information, UIDC, 10/2/80.

Cornia, Gary C. et al., State - Local Fiscal Incentives and Economic Development. (Urban Development Series No.4) Columbus: Academy for Contemporary Problems, June 1978.

Hollister, Robert, Politics of Development, Weshington, DC: National Association of Governors, 1980.

Netional Council on Urben Economic Development. Cases in Urban Economic Development, Washington: NCUED, 1978.

Revised Cooley Place Retail Impact Analysis, Larry Smith \& Co., 1/10/80. 
U.S. Conference of Mayors, CRA: Bridging Public/Private Investment, Washington: USCM, 1979.

U.S., HUD. The Private Economic Dlevelopment Process. (PDR-482) September, 1979.

Newspaper Articles:

"All Systems Go for Copley Place", Boston Globe, 4/30/80.

"Agreement Reached on Copley Jobs", Boston Globe, 4/29/80.

"City Councll clears Way for Copley Plece", Boston Globe, 11/6/00.

"Copley Place Gets State 0.K.", Boston Globe, 2/1/80.

Copley Place Plan Gets an Officlal Start", Boston Globe, 11/14/80.

"Development: It Cuts Both Ways", Boston Globe, 10/15/80/.

"HUD Approves $18.5 \mathrm{~m}$ for Copley Place", Boston Globe, 10/3/80.

"Jobs Issue Sends Copley Into Overtime", Boston Ledger, 4/18-24/80.

"Outlook for Boston: A Boom", Boston Globe, 1/11/81.

"Strike, Lawsuit, Design Issues Beset Copley Place", South Find News, $8 / 20 / 81$.

White: Copley Place Will Die Unless Hub Gets $50 \%$ of Jobs", HereldAmerican, 4/10/80.

White's Grab for Copley Place Jobs", Christian Science Monitor, 4/25/80.

"White Seeks $\$ 20 \mathrm{~m}$ for Copley Place", Boston Globe, 4/10/80.

Interviews:

Lucas DiLeo, Project Coordinator for Copley Place, BRA, 4/13/82.

Frank Keefe, former Director of State Planning, 3/24/82.

Major Lewis, Assistant Project Coordinator for Copley Place, BRA, 3/9/82.

Joseph Orphant, 106 Review Coordinator, Massachusetts Historical Commission, $4 / 12 / 82$.

Frank Smizik, Massachusetts Law Reform Institute, 3/2/82.

Teri Weidner, Director of Communications, DIDC, 3/17/82. 